\title{
Alternative hepatic arterial reconstruction technique in a case of total pancreaticoduodenectomy after celiac artery resection in pancreas cancer: Iliac-hepatic bypass
}

\author{
Mustafa Özsoy ${ }^{1}$, Enes Şahin² ${ }^{2}$ Mustafa Yavuz ${ }^{3}$, Zehra Özsoy ${ }^{4}$, Nazan Okur ${ }^{5}$, Süleyman Şahin' ${ }^{1}$, Sezgin Yılmaz ${ }^{6}$, Yüksel Arıkan ${ }^{6}$ \\ ${ }^{1}$ Clinic of General Surgery, Parkhayat Hospital, Afyonkarahisar, Turkey \\ ${ }^{2}$ Department of General Surgery, Selcuk University School of Medicine, Konya, Turkey \\ ${ }^{3}$ Clinic of General Surgery, Afyon State Hospital, Afyonkarahisar, Turkey \\ ${ }^{4}$ Clinic of Internal Medicine, Afyon State Hospital, Afyonkarahisar, Turkey \\ ${ }^{5}$ Department of Radiology, Süleyman Demirel University School of Medicine, Isparta, Turkey \\ ${ }^{6}$ Department of General Surgery, Afyon Kocatepe University School of Medicine, Afyonkarahisar, Turkey
}

\begin{abstract}
Surgery is the only treatment method in pancreatic cancer. Unfortunately, metastatic diseases or invasion of the main vascular structures are observed in a majority of cases at the time of diagnosis; these structures originate from the body, neck, and tail of the pancreas and are considered inoperable. The first celiac artery resection for the treatment of cancer was described by Appleby in 1953. Here, we describe our hepatic artery reconstruction technique in a case with pancreatic body cancer. A 37-year-old male patient was admitted to our emergency department due to syncope. The patient was diagnosed with acute renal failure secondary to fluid loss. Thereafter, his general condition was stable and laboratory results improved. Abdominal computed tomography was performed. Pancreatic cancer originating from the pancreatic body was detected. A pancreatic biopsy was performed and neoadjuvant gemcitabine and paclitaxel chemoradiotherapy were initiated. Surgical treatment was recommended for the identification of regression after neoadjuvant chemoradiotherapy. Following intraoperative Doppler ultrasonography, en bloc distal pancreatectomy and splenectomy involving the celiac artery trunk and total gastrectomy were performed. However, surgical margin reliability in frozen section revealed that the tumor was still present. Therefore, the surgical procedure was replaced with total pancreaticoduodenectomy. Hepatic artery reconstruction was performed from the left main iliac artery using a 4-mm ringed GORE-TEX ${ }^{\circledR}$ graft. The iliac-hepatic bypass for hepatic artery reconstruction in pancreatic cancer could be an alternative surgical technique.
\end{abstract}

Keywords: Appleby, celiac artery, iliac-hepatic bypass, pancreas

Cite this article as: Özsoy M, Şahin E, Yavuz M, Özsoy Z, Okur N, Şahin S, et al. Alternative hepatic arterial reconstruction technique in a case of total pancreaticoduodenectomy after celiac artery resection in pancreas cancer: Iliac-hepatic bypass. Turk J Surg 2019; 35 (2): 146-150

\section{Corresponding Author}

Mustafa Özsoy

E-mail:dr.mustafaozsoy@gmail.com

Received: 04.02.2017

Accepted: 05.06.2017

Available Online Date: 21.09 .2018

OCopyright 2019 by Turkish Surgical Society Available online at www.turkjsurg.com

DOI: 10.5578/turkjsurg.3983

\section{INTRODUCTION}

Surgery is the only treatment method known to prolong survival in pancreatic cancer, which is one of the most lethal types of cancer. In the standard treatment of cancer originating from the body of the pancreas, splenectomy and distal pancreatectomy are involved; however, resection of the main vascular structures, such as the celiac artery and main hepatic artery, is required to achieve a curative resection (R0) in most cases (1). Unfortunately, there are limited data available on celiac artery resection in the cancer of the pancreatic body. This study aimed to describe our novel hepatic artery reconstruction technique after switching from the Appleby procedure to total pancreaticoduodenectomy in a patient with pancreatic body cancer since intraoperative frozen section revealed that the tumor had remained at the surgical margin.

\section{CASE REPORT}

A 37-year-old male patient was admitted to the emergency department due to syncope. The patient had lost about $30 \mathrm{~kg}$ of weight with increasingly severe abdominal pain in the 3 months before admission. Laboratory tests revealed elevated aspartate aminotransferase (100 U/L), alanine aminotransferase (80 U/L), and creatinine $(2.7 \mathrm{mg} / \mathrm{dL})$; an international normalized ratio of 1.8; and CA19-9 of $200 \mathrm{U} /$ $\mathrm{mL}$. In a focused assessment using sonography for trauma of the abdomen, no free fluids were detected; however, an approximately $6-\mathrm{cm}$ mass of pancreatic origin 
was observed in the upper abdomen. The patient was admitted to the intensive care unit due to acute renal failure secondary to fluid loss. His general condition was stable and laboratory results improved. In a dynamic upper abdominal computed tomography scan, pancreatic cancer that showed no distant organ or peritoneal spread was detected in the splenic, hepatic, and celiac artery originating from the pancreatic body (Figure 1). Additional focus was detected in a positron emission tomography scan. A pancreatic biopsy was performed under the guidance of ultrasonography (USG), and neoadjuvant gemcitabine and paclitaxel chemoradiotherapy were initiated. Surgical treatment was recommended upon the identification of regression after neoadjuvant chemoradiotherapy.

A written informed consent was obtained from the patient. No distant organ metastasis was noted in abdominal exploration. The mesenteric artery and vein were suspended through an extended Kocher maneuver. The hepatoduodenal ligament was dissected and the main hepatic artery, portal vein, and bile duct were suspended. The pancreas was transected from the retropancreatic portal vein level. The main hepatic artery was clamped, and the peak systolic velocity of the hepatic artery was measured as normal (58.60 mL/min) using intraoperative Doppler USG. Following intraoperative Doppler USG and macroscopically adequate hepatic artery pulsation, en bloc distal pancreatectomy and splenectomy, including the celiac artery trunk, and total gastrectomy, were performed. The examination of the specimen sent for surgical margin reliability revealed that the tumor was still present; therefore, we decided to perform pancreaticoduodenectomy. Conventional pancreaticoduodenectomy was completed with gastroduodenal artery connection following a choledochal dissection. Due to the presence of acute renal failure in the patient's history, hepatic artery reconstruction was performed from the left main iliac artery with the help of a 4-mm ringed GORE-TEX ${ }^{\circledR}$ (W. L. Gore \& Associates, Flagstaff, Arizona, USA) graft to minimize

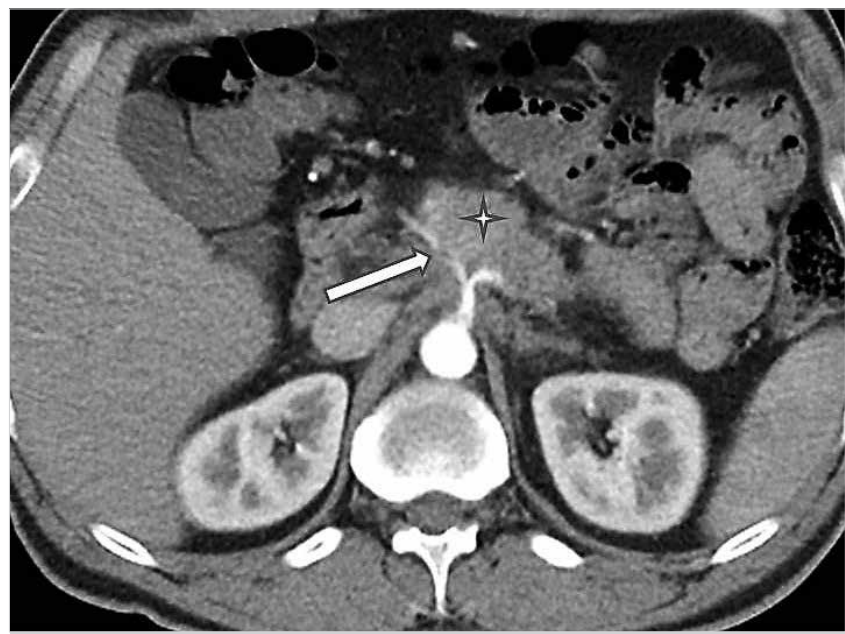

Figure 1. Tumoral mass originating from the pancreatic body (star) and invading the main hepatic and celiac arteries (arrow) was detected.

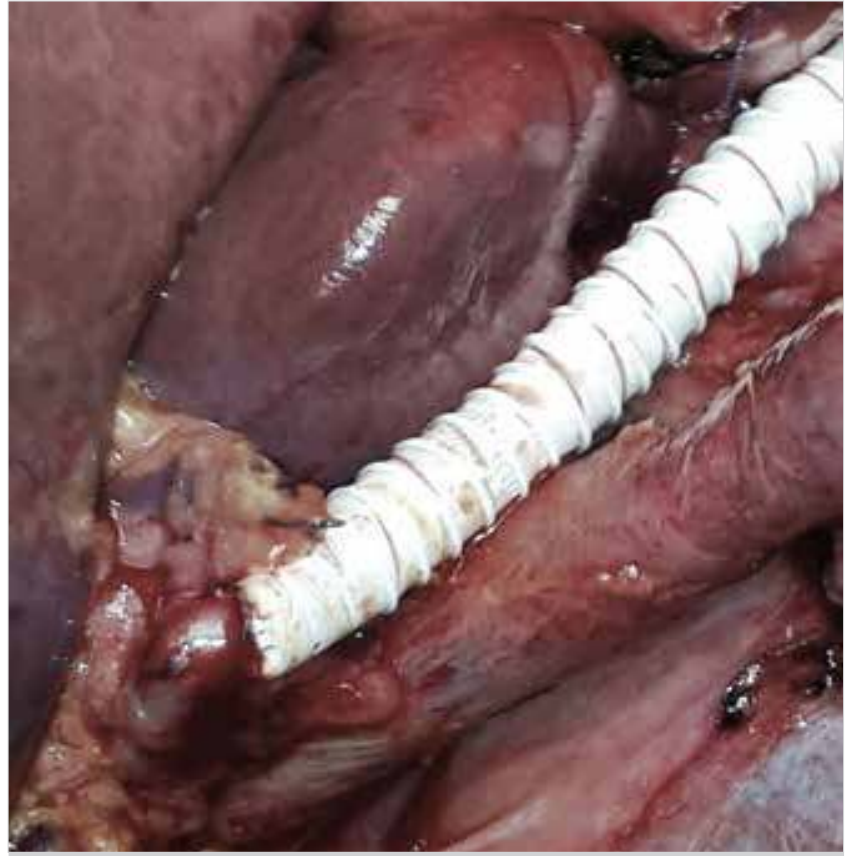

Figure 2. Complete image of intraoperative iliac-hepatic bypass.

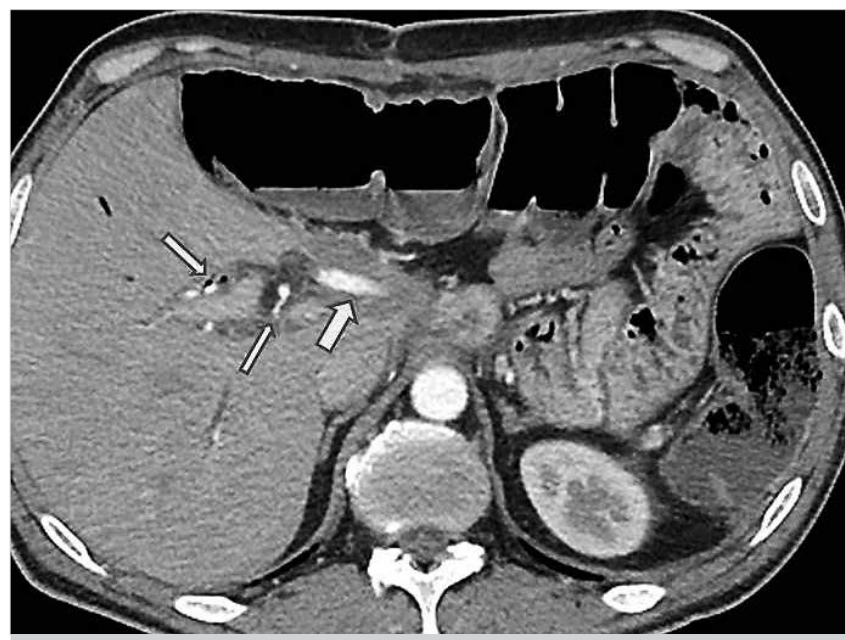

Figure 3. Presence of intrahepatic-hepatic arterial flow (thin arrow) and GORE-TEX ${ }^{\circledR}$ graft (thick arrow) in post-operative control abdominal computed tomography.

the risk of renal ischemia due to aortic clamping. Total duration of the ischemia was $25 \mathrm{~min}$. Hepatic artery flow was $60 \mathrm{~mL} / \mathrm{min}$ in the repeated Doppler USG (Figure 2). Reconstruction was completed with hepaticojejunostomy and esophagojejunostomy. In the post-operative period, blood sugar level of the patient was regulated, and he was discharged on Day 15 following the operation (Figure 3). In post-operative histopathological examination, all surgical margins were found to be negative for tumors. Adjuvant therapy was completed, and the patient is cancer-free and still alive at 22 months after the operation. 


\section{DISCUSSION}

Despite the developments in surgical, adjuvant, and neoadjuvant radio-chemotherapy regimens for the treatment of pancreatic cancer, five-year survival rates are still below the desired targets. In the study by Sohn et al., only 10\%-30\% of pancreatic cancer patients have been reported to be eligible for the surgical treatment (2). Despite a theoretically possible curative (R0) resection due to the resection of major vascular structures and complex reconstructive surgical interventions in locally advanced diseases, severe post-operative morbidity and mortality rates are observed. Therefore, the involvement of adjacent vascular structures in pancreatic cancer is still considered inoperable by most surgeons. In recent years, publications from high-volume centers have become the basis for new discussions on the applicability of superior mesenteric and portal venous resections with acceptable complication rates (3). Although the resection of venous structures in pancreatic cancer and their impact on survival has gained acceptance, the resection of arterial structures remains the center of discussion. However, there are no studies in the literature supporting the non-resection of the arterial structures in actuality. About $30 \%$ of pancreatic cancers are located in the pancreatic body or tail, and cancer in the pancreatic body leads to early celiac and main hepatic artery invasion due to anatomic proximity (4). According to the current guidelines, in cancer cases located in the body and tail of the pancreas, the involvement of the celiac and main hepatic arteries is considered a criterion for non-resectability. However, splenic artery involvement is not included in the inoperability criteria (5).

The first celiac artery resection to treat cancer was described by Appleby in 1953 (6). Appleby identified the presence of adequate hepatic artery flow after celiac artery resection with distal pancreatectomy and splenectomy in a patient with locally advanced gastric cancer. Nimura adapted the surgical technique described by Appleby for the treatment of pancreatic cancers (7). Hepatic artery flow after celiac artery resection is achieved through the pancreaticoduodenal arc originating from the superior mesenteric artery. Although there are no comparative studies on the contribution of celiac artery resection for the survival period, promising results have been obtained in the Almano and Hartwig series in terms of post-operative complications and survival $(8,9)$. Furthermore, the reconstruction of intraoperative hepatic arterial flow after celiac artery resection is essential. Wu et al. have reported that elevated transaminase levels, cholecystitis, and gastric ulcer incidences were detected post-operatively, despite adequate hepatic artery flow through the pancreaticoduodenal arc after celiac artery resection (10). The presence of intraoperative hepatic artery pulsation and no macroscopic discoloration in all of these complications indicate that there may be limitations in determining the adequacy of hepatic artery flow. Excessive lymphatic dissection and resection of border plexuses may cause liver ischemia in the post-operative period due to arterial vasospasm. Therefore, hepatic artery reconstruction, even in the presence of sufficient vascular flow, is thought to reduce gastric and hepatic dysfunction and prevent complications (11). Currently, hepatic artery flow can be detected using intraoperative Doppler USG and hepatic venous oxygenation rather than macroscopical evaluation by pulpability and discoloration of the liver (12). Several different techniques for hepatic artery reconstruction have been described to date. In addition to end-to-end reconstruction, the middle colic artery as well as the saphenous vein or prosthetic graft (GORE-TEX ${ }^{\circledR}$ ) can be used for the reconstruction of the gastroepiploic artery (13). Machado et al. have defined the iliac-hepatic artery revascularization technique using a prosthetic (Dacron ${ }^{\circledR}$ ) hepatic artery reconstruction graft (14). Complications that may be caused by celiac artery resection can be prevented through preoperative celiac artery embolization. Although collateral development in the pancreaticoduodenal arc can be achieved with celiac artery embolization, it should be performed only in patients to be resected $1-2$ days prior to the surgery (15).

In our case, pancreatic cancer originating from the pancreatic body characterized by main hepatic and celiac artery invasion was detected. Upon showing response to preoperative neoadjuvant treatment, surgical treatment was recommended to ensure maximum survival time. Main hepatic artery clamping was performed before celiac artery resection. Meanwhile, as intraoperative Doppler USG scan revealed adequate hepatic artery flow, celiac artery resection and total gastrectomy were added to distal splenopancreatectomy. Due to the invasion of the posterior wall of the stomach by the mass in the pancreas, we decided that removal with total gastrectomy rather than preservation of left gastric artery by reconstruction would be more suitable for reaching the goal of R0 resection. Preoperative celiac artery embolization was not performed oin our patient, as at centers where intraoperative USG and vascular reconstruction can be performed frequently, possible complications arising from embolization can be avoided. Total pancreaticoduodenectomy was recommended based on the finding that the tumor remained in the surgical margin according to the intraoperative frozen section examination. We decided to perform iliac-hepatic bypass for hepatic artery reconstruction via ligation of the gastroduodenal artery as other reconstruction methods required total aortic clamping to achieve adequate artery flow rate. This method was preferred in our case with a history of acute renal failure owing to its ease of application and to avoid additional morbidity. Our patient completed the postoperative adjuvant therapy. He remains cancer-free and is in his $22^{\text {nd }}$ post-operative month.

\section{CONCLUSION}

Vascular resections in pancreatic cancers have high rates of morbidity and mortality. However, due to advanced anesthesia and surgical techniques in high-volume centers, complex recons- 
tructive techniques can be performed with acceptable morbidity and mortality rates.

Informed Consent: Written informed consent was obtained from patient who participated in this study.

Peer-review: Externally peer-reviewed.

Author Contributions: Concept - M.Ö., M.Y.; Design - Z.Ö.; Supervision Y.A., S.Y.; Resource - S.S..; Materials - N.O.; Data Collection and/or Processing - E.Ş., M.Ö.; Analysis and/or Interpretation - Y.A.; Literature Search - Z.Ö.; Writing Manuscript - Z.Ö.; Critical Reviews - S.Y.

Conflict of Interest: The authors have no conflicts of interest to declare.

Financial Disclosure: The authors declared that this study has received no financial support.

\section{REFERENCES}

1. Gagandeep S, Artinyan A, Jabbour N, Mateo R, Matsuoka L, Sher L, et al. Extended pancreatectomy with resection of the celiac axis: the modified Appleby operation. Am J Surg 2006; 192: 330-5. [CrossRef]

2. Sohn TA, Yeo C J, Cameron JL, Koniaris L, Kaushal S, Abrams KA, et al. Resected adenocarcinoma of the pancreas 616 patients: results, outcome, and prognostic indicators. J Gastrointest Surg 2000; 4: 567-79. [CrossRef]

3. Tseng JF, Raut CP, Lee JE, Pisters PW, Vauthey JN, Abdalla EK, el al. Pancreatoduodenectomy with vascular resection: margin status and survival duration. J Gastrointest Surg 2004; 8: 935-49. [CrossRef]

4. Kutluturk K, Alam AH, Kayaalp C, Otan E, Aydin C. En masse resection of pancreas, spleen, celiac axis, stomach, kidney, adrenal, and colon for invasive pancreatic corpus and tail tumor. Case Rep Surg 2013;376035. [CrossRef]

5. Baumgartner JM, Krasinkas A, Daouadi M, Zureikat A, Marsh W, Lee $K$, et al. Distal pancreatectomy with en bloc celiac axis resection for locally advanced pancreatic adenocarcinoma following neoadjuvant therapy. J Gastrointest Surg 2012; 16: 1152-9. [CrossRef]
6. Appleby LH. The coeliac axis in the expansion of the operation for gastric. Cancer 1953; 6: 704-7. [CrossRef]

7. Nimura Y, Hattori T, Miura K, Nakashima N, Hibi M. Resection of advanced pancreatic body-tail carcinoma by Appleby's operation. Shujutu 1976; 30: 885-9.

8. Almano H, Miura F, Toyota N, Wada N, Katoh K, Hayano K, et al. Is pancreatectomy with arterial recontsruction a safe and useful procedure for locally advanced pancreatic cancer? J Hepatobiliary Pancreat Surg 2009; 16: 850-7. [CrossRef]

9. Hartwig W, Hackert T, Hinz T, Hassenpflug M, Strobel O, Büchler M, et al. Multivisceral resection for pancreatic malignancies: riskanalysis and longterm outcome. Ann Surg 2009; 250:81-7. [CrossRef]

10. WuX, Tao R, Lei R, Han B, Cheng D, Shen B, et al. Distal pancreatectomy combined combined with celiac axis resection in treatment of carcinoma of the body/tail of the pancreas: a single center experience. Ann Surg Oncol 2010; 17: 1359-66. [CrossRef]

11. Yamamoto Y, Sakamoto Y, Ban D, Shimada K, Esaki M, Nara S, et al. Is celiac axis resection justified for T4 pancreatic body cancer? Surgery 2012; 151:61-9. [CrossRef]

12. Ielpo B, Ferri V, Caruso R, Duran H, Diaz E, Fabra I, et al. Alternative arterial reconstruction after extended pancreatectomy. Case report and some considerations of locally advanced pancreatic cancer. JOP 2013: 14:432-7.

13. Morera-Ocon FJ, Cárcel-Cárcel I, Vicente JB, González-Cruz VI. Some Reflexions on the Modified Appleby Procedure. JOP 2009; 10: 674-8.

14. Machado MA, Surjan RC, Nishinari K, Makdissi FF, Machado MC. Iliachepatic arterial bypass for compromised collateral flow during modified Appleby operation for advanced pancreatic cancer. Eur J Surg Oncol 2009; 35: 1124-7. [CrossRef]

15. Kondo S, Katoh H, Shimizu T, Omi M, Hirano S, Ambo Y, et al. Preoperative embolization of the common hepatic artery in preparation for radical pancreatectomy for pancreas body cancer. Hepatogastroenterology 2000; 47: 1447-9. 


\title{
OLGU SUNUMU-ÖZET
}

Turk J Surg 2019; 35 (2): 146-150

\section{Pankreas kanserinde çölyak arter rezeksiyonu (appleby) sonrasında alternatif hepatik arteryel rekonstrüksiyon tekniği}

\author{
Mustafa Özsoy ${ }^{1}$, Enes Şahin ${ }^{2}$, Mustafa Yavuz ${ }^{3}$, Zehra Özsoy ${ }^{4}$, Nazan Okur ${ }^{5}$, Süleyman Şahin ${ }^{1}$, Sezgin Yılmaz ${ }^{6}$, Yüksel Arıkan $^{6}$ \\ 1 Parkhayat Hastanesi, Genel Cerrahi Kliniği, Afyonkarahisar, Türkiye \\ 2 Selçuk Üniversitesi Tıp Fakültesi, Genel Cerrahi Anabilim Dalı, Konya, Türkiye \\ ${ }^{3}$ Afyon Şehir Hastanesi, Genel Cerrahi Kliniği, Afyonkarahisar, Türkiye \\ ${ }^{4}$ Afyon Şehir Hastanesi, İç Hastalıkları Kliniği, Afyonkarahisar, Türkiye \\ ${ }^{5}$ Süleyman Demirel Üniversitesi Tıp Fakültesi, Radyoloji Anabilim Dalı, Isparta, Türkiye \\ ${ }^{6}$ Afyon Kocatepe Üniversitesi Tıp Fakültesi, Genel Cerrahi Anabilim Dalı, Afyonkarahisar, Türkiye
}

\section{ÖZET}

Pankreas kanserlerinde yaşam süresine katkı sağlayan tek tedavi seçeneği cerrahidir. Ne yazık ki pankreas gövde, boyun ve kuyruk kesiminden köken alan kanserlerde çoğunlukla metastatik hastalığa veya komşuluk nedeniyle ana vasküler yapılara invazyon saptanarak inoperabl kabul edilmektedir. Çölyak arter rezeksiyonu ilk kez 1953 yıllında lokal ileri evre mide kanserli bir olguda Appleby tarafından uygulanmıştır. Bu makalede pankreas gövde kanserli bir hastada hepatik arteriyel rekonstrüksiyon tekniğimizi sunmayı amaçladık. Otuz yedi yaşında erkek hasta acil servise senkop nedeniyle başvurdu. Hasta sıvı kaybına sekonder akut böbrek yetmezliği tanısıyla yoğun bakım izlemine alındı. Genel durumu düzelen hastanın elde edilen dinamik üst abdomen tomografisinde pankreas gövde kısmından kaynaklanan ana vasküler yapıları içerisine alan uzak organ veya peritoneal yayılım göstermeyen pankreas kanseri saptandı. Pankreas biyopsisi sonrasında gemsitabin ve paklitakselden oluşan neoadjuvan kemoradyoterapi başlandı. Neoadjuvan kemoterapi sonrasında pankreastaki kitlede gerileme saptanması üzerine cerrahi tedavi uygulanmasına karar verildi. İntraoperatif Doppler ultrasonografi (USG) sonrasında çölyak arter ve total gastrektominin ilave edildiği unblok distal pankreatektomi ve splenektomi uygulandı. Lakin intraoperatif frozen incelemede cerrahi sınırın pozitif olması üzerine total pankreatikoduodenektomi uygulanmasına karar verildi. Hepatik arter rekonstrüksiyonu 4 mm’lik ringli goroteks greft yardımıyla sol ana iliyak arterden yapıldı. Çölyak arter rezeksiyonu sonrasında hepatik arteriyel rekonstrüksiyon için goroteks greft yardımıyla iliohepatik baypas uygulama kolaylığı nedeniyle tercih edilebilir bir yöntemdir.

Anahtar Kelimeler: iliohepatik baypas, appleby, pankreas, çölyak arter

Doi: $10.5578 /$ turkjsurg.3983 